\title{
DEVELOPMENT AND APPLICATION OF POTENTIOMETRIC STRIPPING ANALYSIS
}

\author{
LJILJANA M. BABINCEV ${ }^{1 *}$, DEJAN M. GUREŠIĆ ${ }^{1}$, RANKO M. SIMONOVIĆ \\ ${ }^{1}$ Faculty of Technical Sciences, University of Priština, Kosovska Mitrovica, Serbia \\ ${ }^{2}$ Faculty of Natural Sciences and Mathematical, University of Priština, Kosovska Mitrovica, Serbia
}

\begin{abstract}
This paper focuses on the voltammetric determination of lead, cadmium and zinc in water. Two ways of determining were investigated: indi vidually and all three metals simultaneously. The experiments were performed using the Potentiometric Stripping Analysis (PSA). Determination of metals in real samples was preceded by preliminary tests. Preliminary investigations were performed in order to determine the optimal conditions of measurement. It was concluded that the process of determining was for most part influenced by: pH, time of metals extraction, stirring rate of the solution and the thickness of the mercury layer on the working electrode. The s mallest concentrations of metals which can be deter mined using this method are: for lead $22.48 \mu \mathrm{g} \mathrm{dm}^{-3}$, for cadmium $16.23 \mu \mathrm{g} \mathrm{dm}^{-3}$ and for zinc $18.75 \mu \mathrm{gm}^{-3}$. The obtained results de viated from the actual $1.12 \%$ for lead, $\mathbf{1 . 9 1 \%}$ for cadmium and $\mathbf{1 . 8 1 \%}$ for zinc. All tests (indi vidually and simultaneously) were conducted from model solution with concentration as follows: $44.96 \mu \mathrm{g} \mathrm{dm}{ }^{-3}$ for lead, $32.47 \mu \mathrm{g} \mathrm{dm}^{-3}$ for cadmi um and $37.50 \mu \mathrm{g} \mathrm{dm}$ for zinc. The results of individual measurements deviated by $1.02 \%$ lead, $1.90 \%$ for cadmium and $1.89 \%$ for zinc. Simultaneously the contents were lower than real for: $-4.58 \%$ for lead, cadmium for $-1.91 \%$ and $-1.89 \%$ for zinc. For the conditions determined, except for lead, deviations did not exceed $\pm 2 \%$. This indicates that Potentiometric Stripping Analysis is a good way of individual and simultaneous de termination of lead, cadmium and zinc and for determination of their concentrations in water (river and groundwater).
\end{abstract}

Keywords: Lead, Cadmium, Zinc, Potentiometric Stripping Anal ysis, Waters.

\section{INTRODUCTION}

Heavy metals are natural constituents of soil whence are due into waterways and via of plants and in the food chain (Kastori, 1997; Sekulić et al., 2003; Kastori et al., 2006). They are characterized by toxic effects which are manifested in traces. Testing area is the northern part of Kosovo and Metohija. This part is directly affected by 100 million tons of existing flotation landfills of Trepča, which occupy an area of about 350 ha. A voltammetric technique used to determine traces of heavy metals in the surrounding surface water (river) and groundwater (natural spring and borehole) was Potentiometric Stripping Analysis (Wang, 1985; Jin et al., 1997). Determination of metals, by a three-electrode electrolytic system, was preceded by reduction and oxidation processes After reduction of metal ions on the working electrode, at a give potential, extracted metal ions are oxidized with oxygen from the solution and in terms of diffusion mass transfer they return to solution while monitoring the dependence of the potentials from oxidation time (Jagner, 1979; Marjanović et al., 1987; Riso et al, 1999;). This dependence is proportional to material concentrations. The potential of the working electrode does not change until the entire concentrations of the separate elements are oxidized. After complete oxidation of one, the working electrode potential increases to the characteristic potentials at which oxidation of the following element takes place (Suturović, 1985; Suturović, 1992; Stanković et al., 2007; Suturović, 2003).

The aim of this study was: I) To establish conditions for the simultaneous determination of lead, cadmium and zinc using Potentiometric Stripping Analysis; II) Sampling and sample preparation as well as the reduction to a single sample is suitable for Potentiometric Stripping Analysis; III) Application of simultaneous Potentiometric Stripping Analysis for the determination of lead, cad miu m and zinc in water samples.

\section{EXPERIMENTAL}

\section{Apparatus}

The tests in this paper were performed on the device for Potentiometric Stripping Analysis, Striping analy zer M 1 (Faculty of Technology in Novi Sad, Symmetry in Leskovac, Serbia). Basis of this system's functioning is a three-electrode electrolytic cell consisting of: disk working electrode of glassy carbon, the total area of $7.07 \mathrm{~mm}^{2}$, which is used as an inert carrier for the mercury layer; a reference silver-silver chloride electrode $\left(\mathrm{Ag} / \mathrm{AgCl} / \mathrm{KCl} / 3.5 \mathrm{~mol} \mathrm{~d} \mathrm{~m}{ }^{-3}\right)$ and a platinum auxiliary electrode. Metal content using Potentiometric Stripping Analysis were determined by standard addition method (Babincev, 2004).

\footnotetext{
* Corresponding author: 1jiljana.babincev@pr.ac.rs 


\section{Reagents}

All the solutions for the execution of th is experiment were prepared from high purity chemicals (supprapur, Merck). The basic solutions were prepared by standard lead, cadmium, zinc and mercury $\left(1.000 \mathrm{~g} \mathrm{dm}^{-3}\right)$ while working solutions were prepared from the basic standards in the concentrations as follows: for the lead $90 \mathrm{mg} \mathrm{dm}^{-3} 3$, zinc $75 \mathrm{mg} \mathrm{dm}^{-3}$, for cadmium $65 \mathrm{mg} \mathrm{d} \mathrm{m}^{-3}$. In addition to standard solutions, the following ones were also used: hydrochloric acid ( $\mathrm{HCl}, 30 \%)$, nitric-acid (HNO3, 65\%), di-methyl ketone $(\mathrm{CH} 3 \mathrm{COCH} 3,99.5 \%)$, coppersulfate $(\mathrm{CuSO} 4)$ and gallium-chloride $\left(\mathrm{GaCl}_{3}\right)$. The solutions were stored in polyethylene bottles (Babincev, 2004).

\section{Sample preparation}

Sample preparation for Potentiometric Stripping Analysis was done so that the certain amount of filtered water was evaporated after adding $5 \mathrm{ml}$ of concentrated nitrate. The process was repeated three times in order to transform metals into the shape of ions. Following separation and evaporation, the dry residue was dissolved with $5 \mathrm{ml}$ chlorine acid, and adding the ionized water, it has been transferred into the measuring pot of $100 \mathrm{ml}$. A liquot of $20 \mathrm{ml}$ has been transferred into the glass for electrolytic determination by Potentiometric Stripping Analysis (Babincev et al., 2011; Babincev, 2012a; Babincev, 2012b).

\section{Procedure}

Metal determination was preceded by the formation of the working electrode on the surface of glassy carbon from acidic solution of mercury(II)-ion concentration $10 \mathrm{mg} \mathrm{dm}^{-3}$. Mercury film formation at glassy carbon electrode was performed at a constant current of $-48.90 \mu \mathrm{A}$ for the time of $240 \mathrm{~s}$. In order to define optimal experimental conditions for determination of metals, the series of solutions (model solutions) of $20.0 \mathrm{ml}$ of deionized water and $0.5-200 \mu \mathrm{l}$ working standard solutions of lead, cadmium and zinc were prepared (Babincev, 2012c). Working standards were added to a micropipettes with variable volume of $0.10( \pm 0.05)$ to $200( \pm 1) \mu \mathrm{l}$. Extraction of lead, cadmium and zinc from prepared solutions was carried out at potentials of: $-0.999 \mathrm{~V}$ for lead, cadmium to $-1.106 \mathrm{~V}$ and $-1.035 \mathrm{~V}$ for zinc. Simultaneous determination of all three metals was carried out at a negative potential $(-1.400 \mathrm{~V})$ compared to the potential of mercury that is positive (Babincev, 2012). The simultaneous determination of metals was performed after adjusting the $\mathrm{pH}$ and potential of separation (reduction) because in the analysis of strongly acidic solutions, for the reduction potential that is more negative than $-1 \mathrm{~V}$, it comes to hydrogen evolution at the working electrode. For these reasons, the value for the hydrogen evolution potential is increased for the overvoltage of hydrogen on the metals tested. Simultaneous determination of metals was carried out with prior addition of $\mathrm{Ga}$ (III)-ions, in order to prevent the formation of intermetallic compounds of zinc and possibly the present copper. Intermetallic compound in the oxidation process leads to a decrease in signal for zinc, which depends on the ratio of copper and zinc. Studies were performed in model solutions with zinc concentrations of: 37.5, 187.5, and $375.0 \mu \mathrm{g} \mathrm{dm}^{-3}$, and copper concentrations of $10.0,20.0,30.0$ and $35.0 \mu \mathrm{g} \mathrm{dm}^{-3}$. It was found that interference in the determination of zinc can come from the copper concentrations less than $10.0 \mu \mathrm{g} \mathrm{dm}^{-3}$ with an error of up to $30 \%$. By adding gallium of $40.0 \mu \mathrm{g} \mathrm{dm}^{-3}$ in solutions containing copper from $35.0 \mu \mathrm{g} \mathrm{dm}^{-3}$, for wider range of zinc concentration, the creation of their complex is prevented because more stable complex of galliu m and copper is created.

In order to define the conditions of determination, the impact of the following was particularly examined: $\mathrm{pH}$; stirring rate of solution, time of metals separation and time of working electrode formation.

After the conditions were established, the determination of lead, cadmium and zinc in real samples (river and groundwater) was performed.

\section{RES ULTS AND DISCUSS ION}

The influence of $\mathrm{pH}$ solution on the efficiency of determination was examined in the value range from 1.3-4.5 for metal concentrations of $224.30 \mu \mathrm{g} \mathrm{dm}^{-3}$ lead, $162.01 \mu \mathrm{g} \mathrm{dm}^{-3}$ cadmiu m and $375.00 \mu \mathrm{g} \mathrm{dm}^{-3}$ zinc. It was found that the results obtained deviate by $\pm 2 \%$ when the determination were performed from solutions $\mathrm{pH} 1.3,1.6$ and 2.0. The ratio of oxidation time and content, represented as a constant of Potentiometric Stripping Analysis $\left(\mathrm{K} / \mathrm{s} \mathrm{dm} \mathrm{mol}^{-1}\right)$, has the highest value for lead when determination was performed from solution $\mathrm{pH}$ 1.6, for cad mium from solution $\mathrm{pH} 1.6$ and 2.0, and for zinc from the solution $\mathrm{pH}$ 2.1-3.5. Simultaneous determination was performed at $\mathrm{pH} 2.1$, because for a given value of $\mathrm{pH}$ constant of $\mathrm{pH}$ potentiometric stripping analyses for all three metals have the closest values (Fig. 1).

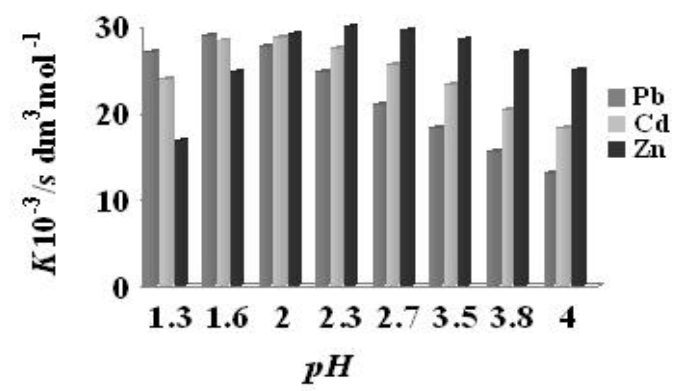

Figure 1. Dependence the constants Potentiometric Stripping Analys is for simultaneous determination of lead, cadmium and zinc by $\mathrm{pH}$ solutions

Effect of stirring rate on the determination of metals was investigated in the range of $1000 \square 6000 \mathrm{~min}-1$. The most efficient determinations have a stirring rate of $4000 \mathrm{~min}-1$, which can be explained by the optimal thickness of diffusion layer of ions in solution. Metal extraction was tested during periods of: $180,240,300,360$ and $420 \mathrm{~s}$. The results of the determination 
showed that the most efficient metal extraction is achieved for the period of $300 \mathrm{~s}$. Contents extracted for the time deviate from the actual by: $1.05 \%$ for lead, $1.90 \%$ for cadmium and $1.94 \%$ for zinc. The least time necessary for metal extraction is $240 \mathrm{~s}$, metal contents extracted for that time deviate from real by: $3.34 \%$ for lead, $3.00 \%$ for cadmiu $m$ and $3.76 \%$ for zinc.

Table 1. The results of the determination of lead concentration in model solutions

\begin{tabular}{|ccccc|}
\hline \multicolumn{2}{|c}{$\begin{array}{c}\text { Concentration of lead } \\
\mu \mathrm{g} \mathrm{dm}^{-3}\end{array}$} & $S^{\mathrm{c}} / \mu \mathrm{g}$ & $K_{\mathrm{v}}{ }^{\mathrm{d}} / \%$ & $E_{\mathrm{r}}^{\mathrm{e}} / \%$ \\
\cline { 1 - 2 }$X_{\mathrm{s}}^{\mathrm{a}}$ & $\bar{X}{ }^{\mathrm{b}}$ & & & \\
\hline 2.25 & 2.38 & 0.30 & 12.60 & 5.78 \\
4.45 & 4.70 & 0.58 & 12.34 & 5.62 \\
22.48 & 24.98 & 2.52 & 11.34 & 1.12 \\
44.96 & 45.42 & 5.15 & 11.34 & 1.02 \\
89.87 & 90.81 & 7.56 & 8.33 & 1.05 \\
224.30 & 226.61 & 18.15 & 8.01 & 1.03 \\
447.50 & 452.20 & 32.92 & 7.28 & 1.05 \\
890.76 & 880.58 & 63.93 & 7.26 & -1.14 \\
1319.16 & 1298.56 & 98.04 & 7.55 & -1.60 \\
1763.84 & 1731.29 & 134.00 & 7.74 & -1.84 \\
2194.05 & 2150.56 & 169.24 & 7.87 & -1.98 \\
2700.00 & 2430.00 & 198.04 & 8.15 & -10.00 \\
\hline
\end{tabular}

$\boldsymbol{X}_{\mathrm{s}}^{\mathrm{a}}$-concentration of elements in the standard solution, $\bar{X}^{\mathbf{b}}$-average measured concentration, number of measurements $=5, S^{\mathbf{c}}$ standard deviation, $\boldsymbol{K}_{\mathbf{v}}{ }^{\mathbf{d}}$-coefficient of variation, $\boldsymbol{E}_{\mathbf{r}}{ }^{\mathbf{e}}$-error determination

Table 2. The results of the determination of cadmium concentration in model solutions

\begin{tabular}{|c|c|c|c|c|}
\hline \multicolumn{2}{|c|}{$\begin{array}{c}\text { Concentration of cadmium } \\
\mu \mathrm{g} \mathrm{dm}^{-3}\end{array}$} & \multirow[t]{2}{*}{$S^{\mathrm{c}} / \mu \mathrm{g}$} & \multirow[t]{2}{*}{$K_{\mathrm{v}}^{\mathrm{d}} / \%$} & \multirow[t]{2}{*}{$E_{\mathrm{r}}^{\mathrm{e}} / \%$} \\
\hline$X_{\mathrm{s}}^{\mathrm{a}}$ & $\bar{X}^{\mathrm{b}}$ & & & \\
\hline 1.62 & 1.73 & 0.03 & 13.96 & 6.79 \\
\hline 3.25 & 3.45 & 0.47 & 13.74 & 6.15 \\
\hline 16.23 & 16.54 & 1.56 & 9.45 & 1.91 \\
\hline 32.47 & 33.09 & 2.49 & 7.54 & 1.90 \\
\hline 64.90 & 66.13 & 4.98 & 7.53 & 1.89 \\
\hline 162.01 & 165.09 & 12.20 & 7.39 & 1.90 \\
\hline 323.22 & 329.31 & 24.45 & 7.43 & 1.88 \\
\hline 643.25 & 634.15 & 45.59 & 7.19 & -1.41 \\
\hline 960.12 & 941.53 & 68.73 & 7.30 & -1.93 \\
\hline 1273.89 & 124323 & 105.79 & 8.51 & -2.40 \\
\hline 1584.59 & 1536.45 & 136.90 & 8.64 & -3.04 \\
\hline 1892.29 & 1789.80 & 156.07 & 8.72 & -5.42 \\
\hline
\end{tabular}

measured concentration, number of measurements=5, $S^{\mathbf{c}}$-standard deviation, $\boldsymbol{K}_{\mathbf{v}}{ }^{\mathbf{d}}$-coefficient of variation, $\boldsymbol{E}_{\mathbf{r}}{ }^{\mathbf{e}}$-error determination

The impact of the mercury layer thickness on metal determination was analyzed as the time required for the formation of the working electrode. The working electrode formation was done by separating the mercury on glassy carbon within: 120, 180, 240, 300 and $360 \mathrm{~s}$. A good reproducibility was obtained for all three ions when the mercury layer was formed within $240 \mathrm{~s}$. The mercury layer formed in $240 \mathrm{~s}$, based on reproducibility, provides a good homogenization of extracted metal ions, easier and faster dissolution process and better separation. In order to determine detection limits of potentiometric analysis for lead, cadmium and zinc, solutions of $20.0 \mathrm{ml}$ of deionized water and different working standard volumes from 0.5 to $600 \mu 1$ were prepared. Metal extraction was performed within $300 \mathrm{~s}$; solution stirring rate of $4000 \mathrm{~min}-1$ and the $\mathrm{pH}$ values were 1.6 for lead and cadmium and 2.1 for zinc. The results for the determination are presented in Tables 1-3.

Table 3. The results of the determination of zinc concentration in model solutions

\begin{tabular}{|c|c|c|c|c|}
\hline \multicolumn{2}{|c|}{$\begin{array}{l}\text { Concentration of zinc } \\
\mu \mu \mathrm{g} \mathrm{dm}^{-3}\end{array}$} & \multirow{2}{*}{$S^{\mathrm{c}} / \mu \mathrm{g}$} & \multirow{2}{*}{$K_{\mathrm{v}}^{\mathrm{d}} / \%$} & \multirow{2}{*}{$E_{\mathrm{r}}^{\mathrm{e}} / \%$} \\
\hline$X_{\mathrm{s}}^{\mathrm{a}}$ & $\bar{X}^{\mathrm{b}}$ & & & \\
\hline 1.88 & 2.02 & & 11.39 & 7.45 \\
\hline 3.75 & 3.97 & 0.23 & 11.59 & 5.86 \\
\hline 18.75 & 19.09 & $\begin{array}{l}0.40 \\
199\end{array}$ & 10.42 & 1.81 \\
\hline 37.50 & 38.21 & $\begin{array}{l}1.99 \\
3.96\end{array}$ & 10.36 & 1.89 \\
\hline 187.50 & 191.15 & $\begin{array}{c}3.90 \\
15.96\end{array}$ & 8.35 & 1.95 \\
\hline 375.00 & 379.77 & $\begin{array}{l}15.96 \\
2827\end{array}$ & 7.43 & 1.27 \\
\hline 750.00 & 737.74 & $\begin{array}{l}28.22 \\
57.47\end{array}$ & 7.79 & -1.63 \\
\hline 1125.00 & 1106.43 & $\begin{array}{l}5 / .41 \\
8077\end{array}$ & 7.30 & -1.65 \\
\hline 1312.50 & 1286.83 & $\begin{array}{c}80.7 / \\
111.70\end{array}$ & 8.68 & -1.95 \\
\hline 1500.00 & 1458.66 & $\begin{array}{l}111.10 \\
130.55\end{array}$ & 8.95 & -2.76 \\
\hline
\end{tabular}

$\boldsymbol{X}_{\mathrm{s}} \mathbf{a}$-concentration of elements in the standard solution, $\bar{X}^{\mathbf{b}}$-average measured concentration, number of measurements=5, $S^{\mathbf{c}}$ standard deviation, $\boldsymbol{K}_{\mathbf{v}}{ }^{\mathbf{d}}$-coefficient of variation, $\boldsymbol{E}_{\mathbf{r}}{ }^{\mathbf{e}}$-error determination

Based on results presented, the minimum contents of lead, cadmium and zinc that were determined with an error of $\pm 2 \%$ are: $22.48 \mu \mathrm{g} \mathrm{d} \mathrm{m}^{-3}$ of lead (determined with an error of $1.12 \%$ ), $16.23 \mu \mathrm{g} \mathrm{d} \mathrm{m}^{-3}$ cadmium (determined with an error of $1.91 \%$ ) and $18.75 \mu \mathrm{g} \mathrm{dm}^{-3}$ zinc (determined with an error of $1.81 \%$ ). In accordance with the standard deviations and the reproducibility, these contents can be considered the limits of determination. Standard deviations were $2.52 \mu \mathrm{g}$ for lead, $1.56 \mu \mathrm{g}$ of cadmium and $1.99 \mu \mathrm{g}$ of zinc. The detection limit of Potentiometric Stripping Analysis for lead, cadmium and zinc is about $20 \mu \mathrm{g}$ $\mathrm{dm}^{-3}$. The highest concentrations that are determined by PSA with an error $\pm 2 \%$ were: $2194.05 \mu \mathrm{g} \mathrm{dm}^{-3}$ for lead; $960.12 \mu \mathrm{g}$ $\mathrm{dm}^{-3}$ for cadmiu m and $1312.50 \mu \mathrm{g} \mathrm{dm}^{-3}$ for zinc. These contents were determined with the error of: $-1,98 \%$ for lead, $-1.93 \%$ for cadmium, and $-1.95 \%$ for zink and standard deviations of: $169.24 \mu \mathrm{g}$ for lead, $68.73 \mu \mathrm{g}$ for cadmium and $111.70 \mu \mathrm{g}$ for zinc.

\section{Simultaneous determinations}

The determination of elements was studied simultaneously in $20.0 \mathrm{ml}$ of deionized water and $10 \mu \mathrm{l}$ working standard solutions of lead, cadmiu m and zinc, for metal concentrations of: $44.96 \mu \mathrm{g} \mathrm{dm}^{-3}$ lead, $32.47 \mu \mathrm{g} \mathrm{dm}^{-3}$ cadmium and $37.50 \mu \mathrm{g} \mathrm{dm}^{-3}$ zinc. Results of this study have shown that potential of the working electrode for the simultaneous determination of lead, cadmium and zinc is $490-510 \mathrm{mV}$ more negative than the potential of zinc dissolution (an element with the lowest redox potential). It was determined that all three elements can be determined at a negative potential $(-1.400 \mathrm{~V})$ in relation to the 
potential of mercury that is positive. For that reason, values for extraction potentials are increased by hydrogen overvoltage on mercury, lead, cadmium and zinc. The simultaneous determination of lead and cadmium has shown optimal values for $\mathrm{pH}$ 1.6. For $\mathrm{pH} 2.1$, cadmium and zinc were simultaneously determined. Simultaneous determination of lead and zinc was examined for $\mathrm{pH} 1.3,1.6,2.0$, the most effective determinations were for $\mathrm{pH}$ 2.0. Zinc is most accurately determined for $\mathrm{pH}$ value of 2.3-3.5, which may partly be explained by the qualitative properties of zinc. The simultaneous determination of all three elements was performed (with the mentioned separation potential) for $\mathrm{pH} 2.1$, because the constants of Potentiometric Stripping Analysis for this value were the closest.
With prior $\mathrm{pH}$ adjustment, metal content was determined by standard addition method. During the determination, metals are firstly reduced (separated) on working electrode and then (after electrolysis) they are oxidized (returned) to the solution. After returning to the solution, oxidation potential is registered, which is changed until the entire separated contents of one metal is returned to the solution. After returning one element to the solution, working electrode potential increases to characteristic potential at which oxidation of the following takes place. Results of simultaneous determination of lead, cadmium and zinc are given in Table 4.

Table 4. The results of the simultaneously determination of lead, cadmium and zinc in model solution

\begin{tabular}{|c|c|c|c|c|c|c|c|c|}
\hline \multirow{2}{*}{ Ion } & \multicolumn{3}{|c|}{ Ion concentration, $\mu \mathrm{g} \mathrm{dm}^{-5}$} & \multirow{2}{*}{$\begin{array}{c}\tau \\
(\mathrm{s})\end{array}$} & \multirow{2}{*}{$\begin{array}{c}K \cdot 10^{-5} \\
\left(\mathrm{~s} \cdot \mathrm{dm}^{3} / \mathrm{mol}\right)\end{array}$} & \multirow{2}{*}{$\begin{array}{c}S \\
(\mu \mathrm{g})\end{array}$} & \multirow{2}{*}{$\begin{array}{c}K_{\mathrm{v}} \\
(\%)\end{array}$} & \multirow{2}{*}{$\begin{array}{c}E_{r} \\
(\%)\end{array}$} \\
\hline & $X_{\mathrm{s}}$ & $X_{\mathrm{i}}$ & $\bar{X}$ & & & & & \\
\hline \multirow{5}{*}{$\mathrm{Pb}^{2+}$} & \multirow{5}{*}{44.96} & 44.63 & \multirow{5}{*}{42.90} & 1.47 & 32.84 & \multirow{5}{*}{5.57} & \multirow{5}{*}{12.98} & \multirow{5}{*}{-4.58} \\
\hline & & 40.98 & & 1.31 & 31.97 & & & \\
\hline & & 43.18 & & 1.40 & 32.47 & & & \\
\hline & & 42.18 & & 1.35 & 32.12 & & & \\
\hline & & 43.56 & & 1.42 & 32.63 & & & \\
\hline \multirow{5}{*}{$\mathrm{Cd}^{2+}$} & \multirow{5}{*}{32.47} & 34.75 & \multirow{5}{*}{31.86} & 0.85 & 24.64 & \multirow{5}{*}{4.54} & \multirow{5}{*}{14.26} & \multirow{5}{*}{-1.91} \\
\hline & & 32.13 & & 0.79 & 24.65 & & & \\
\hline & & 28.96 & & 0.71 & 24.58 & & & \\
\hline & & 33.96 & & 0.84 & 24.82 & & & \\
\hline & & 29.50 & & 0.72 & 24.50 & & & \\
\hline \multirow{5}{*}{$\mathrm{Zn}^{2+}$} & \multirow{5}{*}{37.50} & 41.94 & \multirow{5}{*}{36.79} & 0.90 & 21.56 & \multirow{5}{*}{4.47} & \multirow{5}{*}{12.14} & \multirow{5}{*}{-1.89} \\
\hline & & 35.48 & & 0.76 & 21.49 & & & \\
\hline & & 34.18 & & 0.73 & 21.50 & & & \\
\hline & & 44.40 & & 0.96 & 21.60 & & & \\
\hline & & 36.25 & & 0.78 & 21.58 & & & \\
\hline
\end{tabular}

${ }^{\mathrm{a}} X_{\mathrm{s}}$-concentration of the elements in the model solution, ${ }^{\mathrm{m}} X_{\mathrm{i}}$-measured concentration, ${ }^{\mathrm{b}} \bar{X}$-average measured concentration, number of measurements $=5,{ }^{\mathrm{n}} \tau$-time of oxidation, $K_{\mathrm{p}}$-constant stripping analy sis, ${ }^{\mathrm{c}} S$-standard deviation, ${ }^{\mathrm{d}} K_{v}$-coefficient of variation, ${ }^{\mathrm{e}} E_{\mathrm{r}}$-error determination

The obtained results suggest that there is a difference in the determinate contents when we take individual and simultaneous determinations into consideration. The results for the individual determinations deviated from the actual values by $1.02 \%$ for lead; $1.90 \%$ for cadmium and $1.89 \%$ for zinc. During the simultaneous determinations, the deviations were as follows: $-4.58 \%$ for lead; $-1.91 \%$ for cadmium and $-1.89 \%$ for zinc. Results obtained for lead were less accurate. As it is about micro quantities, having in mind small standard deviations of simultaneous determination in relation to individual, simultaneous determination of these elements is considered possible. Potentiometric Stripping Analysis is applied in determination of heavy metals in samples of different nature (Ka ličan in et al., 2001a; Kaličanin et al., 2001b; Ka ličan in et al., 2001c; Suturović et al., 2001: Kaličanin et al., 2002). In this work, lead, cadmium and zinc in samples of waters are determined. The results for determination of the concentrations of lead, cadmium and zinc in river water (sampled successively every three months starting from april 2015 to february 2016) are shown respectively in Tables $5-8$.
Table 5. The results of concentrations of lead, cadmium and zinc $\left(\mu \mathrm{g} \mathrm{d} \mathrm{m}^{-3}\right)$ in water of the river Ibar, april 2015

\begin{tabular}{|cccc|}
\hline & $\mathrm{Pb}$ & $\mathrm{Cd}$ & $\mathrm{Zn}$ \\
\hline 1 & 4.28 & 0.51 & 29.23 \\
2 & 1.98 & 1.12 & 78.12 \\
3 & 9.24 & 5.25 & 258.43 \\
4 & 10.93 & 4.91 & 180.04 \\
5 & 8.82 & 4.96 & 288.02 \\
6 & 12.11 & 3.85 & 249.11 \\
$M C L$ & 10.00 & 3.00 & 3000.00 \\
\hline
\end{tabular}

Sample 1. Ibar River, the entrance to KM (pontoon bridge), a few kilometers away from the river flows into minutiae, Trepčanska rivers and river peeler; Sample 2. The river Ibar, output from the KM, after casting sundries and peeler, below the city waste disposal Upper Field at Dudinog rubble; Sample 3. The river Ibar, rudarački bridge downstream from the waste disposal,, Trepča,, near the Trepča RMHK in Zvecan; Sample 4. River Ibar bridge Grabovac-Žitkovac, exit behind the city waste disposal Žitkovac; Sample 5. Ibar River, the village Kutnje, entrance to Leposavić, in addition to the city waste disposal Bostaniste in Leposavić; Sample 6. Ibar River, the village of Gornji Krnjin, exit from Leposavić, in addition tailing impoundments Gornji Krnjin in Leposavić; $M C L$ maximum contaminant. 
Results of testing in a small number of cases show exceeding the $M C L$. Lead concentrations above the allowed $M C L$ in the spring season are registered only in the samples 4 and 6 , which refer to water of Ibar. These samples are taken from the bridge Grabovac-Žitkovac behind the place of the waste disposal Žitkovac and in the village Upper Krnjin, the output from Leposavić, in addition to the landfill tailing upper Krnjin or Bostaniste in Leposavić

Table 6. The results of concentrations of lead, cadmium, zinc $\left(\mu \mathrm{g} \mathrm{d} \mathrm{m}^{-3}\right)$ in water of the Ibar, august 2015

\begin{tabular}{|cccc|}
\hline & $\mathrm{Pb}$ & $\mathrm{Cd}$ & $\mathrm{Zn}$ \\
\hline 1 & 2.98 & 0.31 & 29.77 \\
2 & 4.27 & 4.10 & 379.31 \\
3 & 7.64 & 4.36 & 439.18 \\
4 & 8.93 & 4.16 & 338.99 \\
5 & 6.33 & 2.01 & 188.73 \\
6 & 7.56 & 2.13 & 178.54 \\
$M C L$ & 10.00 & 3.00 & 3000.00 \\
\hline
\end{tabular}

Table 7. The results of concentrations of lead, cadmium, zinc $\left(\mu \mathrm{g} \mathrm{d} \mathrm{m}^{-3}\right)$ in water of the river Ibar, october 2015

\begin{tabular}{|cccc|}
\hline & $\mathrm{Pb}$ & $\mathrm{Cd}$ & $\mathrm{Zn}$ \\
\hline 1 & 1.92 & 0.28 & 18.91 \\
2 & 1.72 & 0.59 & 79.93 \\
3 & 6.05 & 2.97 & 29.79 \\
4 & 4.90 & 3.09 & 27.68 \\
5 & 7.79 & 2.01 & 109.59 \\
6 & 9.65 & 2.07 & 129.56 \\
$\mathrm{MCL}$ & 10.00 & 3.00 & 3000.00 \\
\hline
\end{tabular}

Table 8. The results of concentrations of lead, cadmium, zinc $\left(\mu \mathrm{g} \mathrm{m}^{-3}\right)$ in water of the Ibar, february 2016

\begin{tabular}{|cccc|}
\hline & $\mathrm{Pb}$ & $\mathrm{Cd}$ & $\mathrm{Zn}$ \\
\hline 1 & 2.53 & 0.21 & 37.96 \\
2 & 3.98 & 0.49 & 456.01 \\
3 & 5.99 & 2.38 & 337.89 \\
4 & 5.43 & 2.97 & 579.77 \\
5 & 4.12 & 1.97 & 455.99 \\
6 & 4.43 & 1.78 & 337.97 \\
$M C L$ & 10.00 & 3.00 & 3000.00 \\
\hline
\end{tabular}

The increase in lead content in these samples there was probably washing and filtration with a delay of those cities, and cities delays that are located upstream or on the bank of the Ibar. Near the MCL and the concentration of lead in the samples 3 and 5 , which were taken from the measuring points are also close to the waste disposal. Lead is present in the water at the measuring point 1 , which was chosen as the site of male pollution. How is this place located a few kilometers from the flows of the river Sitnica Trepčanska river and river Lushta into the river Ibar, and of all places of disposal of industrial waste, it can be assumed that the lead content in the sample contribute to exhaust fumes of motor vehicles on the road that passes by the banks of the Ibar River, as well as washing with as phalt street.

The minimum content of lead in the Ibar river water was found in the sample 2, which can be explained by the fact that the sampling is done with the left bank of the Ibar river, opposite the city delay the Top Field. This measuring point is the furthest from the city traffic as a possible source of lead contamination. Increased concentrations of cadmium in the river water Ibar at the measuring points $3,4,5$ and 6 above $M C L$ is probably from the same causes as the increased concentration of lead. Sample 1 contains little cadmium. In sample 2 also has a low content of cadmium, but more than in a sample1.This measuring point is the first in a series in which the mixed water of the river Ibar, Sitnica, Trepčanska river and Lushta, which are before the casting of the Ibar already polluted. The content of zinc, compared with $M C L$ is significantly lower compared to lead and cadmium. As his low concentrations it can be said that the existing pollutants in the area tested not significantly affect the water pollution zinc. The results of the content of heavy metals in water samples taken at the same measuring points and in different seasons of the year have shown that there are certain differences, but it is noted the same trend of the contamination, that is determined by the measuring points are more polluted than the other.

The highest concentrations of lead in the samples from the measuring points $3.4,5$, and 6 and the highest concentration of cadmium also at locations 3,4 and 5. The results of determining the content of heavy metal in the spring and of Well water are shown in Tables 9-16.

Table 9. The results of concentrations of lead, cadmiu m and zinc $\left(\mu \mathrm{g} \mathrm{d} \mathrm{m}^{-3}\right)$ in natural spring water, april 2015

\begin{tabular}{|cccc|}
\hline Samples & $\mathrm{Pb}$ & $\mathrm{Cd}$ & $\mathrm{Zn}$ \\
\hline 1 & 1.73 & 1.34 & 79.01 \\
2 & 2.09 & 1.52 & 38.97 \\
$M C L$ & 10.00 & 3.00 & 3000.00 \\
\hline
\end{tabular}

Samples: 1. Village Grabovac, the source is above the alluvial plain. Water pumped from mountainous Lipe; 2 . Devine water, $10 \mathrm{~km}$ from Zvecan

Table 10. The results of concentrations of lead, cadmiu m, zinc $\left(\mu \mathrm{g} \mathrm{dm}^{-3}\right)$ in natural spring water

\begin{tabular}{|cccc|}
\hline Samples & $\mathrm{Pb}$ & $\mathrm{Cd}$ & $\mathrm{Zn}$ \\
\hline 1 & 3.01 & 0.83 & 0.25 \\
2 & 2.13 & 2.41 & 0.59 \\
$M C L$ & 10.00 & 3.00 & 30000 \\
\hline
\end{tabular}

Table 11. The results of concentrations of lead, cadmiu m, zinc $\left(\mu \mathrm{g} \mathrm{d} \mathrm{m}^{-3}\right)$ in natural spring water, octobert 2015

\begin{tabular}{|cccc|}
\hline Samples & $\mathrm{Pb}$ & $\mathrm{Cd}$ & $\mathrm{Zn}$ \\
\hline 1 & 1.87 & 0.39 & 38.83 \\
2 & 0.89 & 1.01 & 29.01 \\
$M C L$ & 10.00 & 3.00 & 3000.00 \\
\hline
\end{tabular}

Table 12. The results of concentrations of lead, cadmiu m, zinc $\left(\mu \mathrm{gd} \mathrm{m}^{-3}\right)$ in natural spring water, february 2016

\begin{tabular}{|cccc|}
\hline Samples & $\mathrm{Pb}$ & $\mathrm{Cd}$ & $\mathrm{Zn}$ \\
\hline 1 & 1.18 & 1.03 & 80.34 \\
2 & 1.01 & 1.19 & 83.57 \\
$M C L$ & 10.00 & 3.00 & 3000.00 \\
\hline
\end{tabular}


Table 13. The results of concentrations of lead, cadmium and zinc $\left(\mu \mathrm{g} \mathrm{dm}^{-3}\right)$ in groundwater, april 2015

\begin{tabular}{|c|c|c|c|c|c|c|c|c|c|c|}
\hline Samples & 1 & 2 & 3 & 4 & $6^{*}$ & 7 & 8 & 9 & 10 & $\overline{M C L}$ \\
\hline $\mathrm{Pb}$ & 3.17 & 2.02 & 6.43 & 1.97 & & 1.13 & 3.24 & 1.07 & 6.81 & 10.00 \\
\hline $\mathrm{Cd}$ & 0.69 & 0.84 & 1.89 & 2.27 & & 1.47 & 1.48 & 1.38 & 2.66 & 3.00 \\
\hline $\mathrm{Zn}$ & 28.03 & 39.12 & 149.21 & 59.33 & & 178.56 & 177.92 & 98.16 & 247.77 & 3000.00 \\
\hline
\end{tabular}

Samples groundwater-stone wells: 1. Žitkovac Village, $200 \mathrm{~m}$ of the Ibar, $2 \mathrm{~m}$ from the main road, the age of 5 years; 2 . Village Grabovc, $100 \mathrm{~m}$ of the Ibar, the main road, 30 years old; 3 . Village Žitkovac, $50 \mathrm{~m}$ from the landfill Žitkovac, $200 \mathrm{~m}$ of the Ibar; 4 . The village Rudare, $50 \mathrm{~m}$ from Ibra, 30 years; 5. Village Srbovac, $20 \mathrm{~m}$ from Ibra, 40 years; 6. Villa ge Srbov ac, $20 \mathrm{~m}$ from Ibro, 40 y ears; 7 . The upper Krnjin Village, $100 \mathrm{~m}$ of the Ibar, 10 y; Drilled wells: 8 village Rudare, $80 \mathrm{~m}$ from Ibra, 25 years; 9. Village Grabovac, $30 \mathrm{~m}$ from Ibra, 25 years; 10 . Village Grabovac, $30 \mathrm{~m}$ from Ibra, 25 years; $*$ The planned samples 5 and 6 were not taken due to heavy rainfall

Table 14. The results of concentrations of lead, cad miu mand zinc $\left(\mu \mathrm{g} \mathrm{dm}^{-3}\right)$ in groundwater, august 2015

\begin{tabular}{|cccccccccccc|}
\hline Samples & 1 & 2 & 3 & 4 & 5 & 6 & 7 & 8 & 9 & 10 & $M C L$ \\
\hline $\mathrm{Pb}$ & 3.42 & 0.81 & 9.84 & 5.99 & 4.13 & 3.25 & 1.38 & 5.72 & 3.17 & 14.99 & 10.00 \\
$\mathrm{Cd}$ & 0.21 & 0.15 & 0.91 & 0.07 & 0.13 & 0.36 & 0.57 & 0.02 & 0.47 & 0.41 & 3.00 \\
$\mathrm{Zn}$ & 49.01 & 198.91 & 49.02 & 38.97 & 29.03 & 48.91 & 79.05 & 598.13 & 129.44 & 189.21 & 3000.00 \\
\hline
\end{tabular}

Table 15. The results of concentrations of lead, cadmiu mand zinc $\left(\mu \mathrm{g} \mathrm{dm}^{-3}\right)$ in groundwater, october 2015

\begin{tabular}{|cccccccccccc|}
\hline Samples & 1 & 2 & 3 & 4 & 5 & 6 & 7 & 8 & 9 & 10 & $M C L$ \\
\hline $\mathrm{Pb}$ & 1.89 & 0.79 & 7.11 & 3.65 & 4.81 & 6.32 & 0.99 & 3.71 & 4.02 & 24.09 & 10.00 \\
$\mathrm{Cd}$ & 0.16 & 0.24 & 0.21 & 0.06 & 1.01 & 0.87 & 0.06 & 1.73 & 0.59 & 0.79 & 3.00 \\
$\mathrm{Zn}$ & 29.01 & 38.99 & 19.94 & 39.01 & 33.80 & 48.90 & 38.89 & 399.01 & 258.90 & 568.99 & 3000.00 \\
\hline
\end{tabular}

Table 16. The results of concentrations of lead, cadmiu mand zinc $\left(\mu \mathrm{g} \mathrm{d} \mathrm{m}^{-3}\right)$ in groundwater, february 2016

\begin{tabular}{|cccccccccccc|}
\hline Samples & 1 & 2 & 3 & 4 & 5 & 6 & 7 & 8 & 9 & 10 & $M C L$ \\
$\mathrm{~Pb}$ & 2.58 & 2.61 & 6.13 & 4.23 & 3.81 & 3.74 & 1.02 & 4.13 & 4.43 & 4.21 & 10.00 \\
$\mathrm{Cd}$ & 0.18 & 0.51 & 0.11 & 0.69 & 1.84 & 1.49 & 0.09 & 1.21 & 0.75 & 1.68 & 3.00 \\
$\mathrm{Zn}$ & 249.3 & 138.1 & 149.2 & 189.9 & 60.2 & 97.8 & 43.9 & 279.9 & 462.5 & 431.3 & 3000.00 \\
\hline
\end{tabular}

Significantly, based on the result of determining that the concentration of lead in all the samples wells and water sources is less than the $M C L$ for drinking water. Variations may occur in the lead content at the measuring point 10 (in the drilled wells in the village Grabovac), wherein the concentration $i$ Increased content of lead probably arose due to the reduced quantity of water (drought) and the pumping raises the sediment and stirred with water, which was noticeable by the color of the sample.n the summer and autumn rather above the $M C L$ of the drinking water (Službeni glasnik Republike Srbije, 1994). In the colder period of the year (autumn and winter) lead content is generally lower. Concentrations of cadmium and zinc in well and spring waters are also less than the Maximu m allowable concentrations at all measuring points and in different seasons.

\section{CONCLUSION}

The objective of this study is simultaneous determination of lead, cadmium and zinc by stripping analysis, as well as application of the same in water analysis, establishment of determination conditions, extraction potential, extraction time, optimal solution stirring rate, $\mathrm{pH}$, time of working electrode formation, as well as manner of samples preparation, using the approach of comparing the results of simultaneous with the results of individual determination. It is obvious that there is a difference in results obtained. The efficiency of the individual determination was greater due to the better synchronization of the solution $\mathrm{pH}$ value and the extraction potential. Results accomplished in case of simultaneous determination have shown somewhat lower values which can be explained by the occurrence of hydrogen extraction in the analysis of acidic solutions, when extraction potential is more negative than -1 $\mathrm{V}$. The maximum efficiency for all determinations was obtained at metal extraction time of $300 \mathrm{~s}$, on electrode that is formed in $240 \mathrm{~s}$ and at solution stirring rate of $4000 \mathrm{~min}^{-1}$. At higher stirring rates, the determination efficiency is reduced due to the decreased diffusion layer thickness. The lowest concentrations which can efficiently be determined by Potentiometric Stripping Analysis are: $22.48 \mu \mathrm{g} \mathrm{dm}^{-3}$ for lead, $16.23 \mu \mathrm{g} \mathrm{dm}^{-3}$ for cadmiu m and $18.75 \mu \mathrm{g} \mathrm{dm}^{-3}$ for zinc. Good efficiency is up to $2194.05 \mu \mathrm{g} \mathrm{dm}^{-3}$ for lead, $960.12 \mu \mathrm{g} \mathrm{dm}^{-3}$ for cadmium and $1312.50 \mu \mathrm{g} \mathrm{dm}^{-3}$ for zinc, which can be attributed to identical mechanism of mass transfer during extraction for the one during metal dissolution. For the simultaneous determination of all three metals, determination error was in range of $2-5 \%$. The reproducibility of these measurements for lead, cadmium and zinc in the water samples ranged from: $10-13 \%$ for lead, $10-14 \%$ for cadmium and $8-9 \%$ for zinc. The obtained results indicate that Potentiometric Stripping Analysis is efficient in determination 
of lead, cadmium and zinc, both individually and simu ltaneously, as well as in the analys is of water.

\section{REFERENCES}

Babincev, Lj. 2004. Analiza sadržaja teških metala u vodama oko jalovišta rudnika Suva ruda. Belgrade: Faculty of Technology and Metallurgy., p. 149. MSc thesis (in Serbian).

Babincev, Lj. 2012a. Heavy metals sorption woter from fiber natural. Voda i sanitarna tehnika, 41(2), pp. 59-64.

Babincev, Lj. M., Rajaković, Lj. V., Budimir, M. V., Perić-Grujić, A. A., \& Sejmanović, D. M. 2011. Woody plant willow finction in river water protection. Hem. Ind., 65(4), pp. 397-401.

Babincev, Lj.M., 2012b. Zaštita vodenih resursa primenom prirodnih vunenih vlakana. Ecologica, 67(19), pp. 345-349.

Babincev, Lj. 2012c. Razvoj i primena potenciometrijske striping analize za određivanje teških metala $\mathrm{u}$ ekosistemu. Kosovska Mitrovica: Faculty of Technical Sciences., p. 170. $\mathrm{PhD}$ (in Serbian).

Jagner, D. 1979. Potentiometric stripping analysis in nondeaerated samples. Anal. Chem., 51, p. 324.

Jin, W. R., Nguyen, V. D., Valenta, P., \& Nurnberg H. W., 1997. Simultaneous determination of 7 toxic trace and or ultratrace metals in environmental plants by differentialpulse voltammetry without change of solution and eledtrode. Anal. Lett., 30, p. 1235.

Kaličanin, B.M., Marjanović, N.J., \& Suturović, Z. J. 2001 a. Determination of the soluble lead in the glass ware by the potentiometric stripping analysis. APTEFF, 32, p. 61.

Kaličanin, B.M., Marjanović, N.J., \& Suturović, Z.J. $2001 \mathrm{~b}$. The development of a gigh sensitivity method for the eleetrochemical determination of soluble lead in glassware. HMIDA, 8(55), p. 367.

Kaličanin, B.M., Todorović, Z.B., Marijanović, N.J., \& Suturović, Z.J. 2001c. Potetntiometric stripping Anlysis of soluble lead in the glassware used for needs of food and pharmaceutical industry. J. Chem. Environ, 5, p. 7.

Kaličanin, B.M., Marjanović, N.J., \& Suturović, Z.J. 2002. Application of Potentiometric stripping analysis with constant inverse current in the analytic step for determining lead in glassware. J. Serb. Chem. Soc., 67, p. 213.

Kastori, R. 1997. Heavy metals in the environment, Scientific Institute for Husbandry and Vegetable Crops. Novi Sad., p. 301.

Kastori, R., Bogdanović, D., Kádár, I., Milošević, N., Sekulić, P., \& Pucarević, M. 2006. Soil and plant sampling in unpolluted and polluted habitats. Novi Sad: Scientific Institute for Husbandry and Vegetable Crops., p. 244.

Marjanović, N.J., Suturović, Z.J., Jankovitš, I.F., Ružić, N., \& Branković, V. 1987. Compilation of works. Novi Sad, Serbia: Faculty of Technology., p. 53. 18.

Službeni glasnik Republike Srbije 1994. Pravilnik o dozvoljenim količinama opasnih i štetnih materija $u$ zemljištu i vodi za navodnjavanje i metodama njihovog is pitivanja. Službeni glasnik Republike Srbije, 23, p. 553. (in Serbian).

Riso, R.D., Leccore, P., \& Chaumery, C.J. 1999. Rapid and simultaneous analys is of trace metals $(\mathrm{Cu}, \mathrm{Pb}$ and $\mathrm{Cd})$ in seawater by potentiometric stripping analysis . Anal. Chim. Acta, 83, p. 351.

Sekulić, P., Kastori, R., \& Hadžić, V. 2003. Degradation soil protection, Scientific Institute for Husbandry and Vegetable Crops. Novi Sad., p. 230.

Stanković, S., Čičkarić, D., \& Marković, J. 2007. Determination of $\mathrm{Pb}$ and $\mathrm{Cd}$ in Water by potentiometric stripping analysis (PSA), Desalination 213, pp. 282-287.

Suturović, Z. 1985. Ispitivanje uslova predelektrolize kao prve faze elektrohemijske striping analize. Novi Sad, Serbia: Faculty of Technology., p. 115. MSc thesis (in Serbian).

Suturović, Z. 1992. Povećanje osetljivosti potenciometrijske striping analize. Novi Sad, Serbia: Faculty of Technology., p. 124. PhD thesis.

Suturović, Z.J. 2003. Elektrochem. Stripping Analysis. Novi Sad, Serbia: Faculty of Technology., p. 120.

Suturović, Z.J., Marjanović, N.J., Pekić, B., \& Adamović, D. 2001. Potentiometric stripping analysis of selected heavy metals in roadside chamo mile flower. APTEF, 32, p. 157.

Wang, J. 1985. Stripping Analysis.Derfield Beach, Florida: VCH Publishers., p. 119. 